\title{
A SIMPLIFIED CONNECTION OF HEV AC/AC POWERTRAIN
}

The paper deals with a simplified configuration of series HEV hybrid vehicles. Simplification consists of the downsizing of auxiliary 4QC converter needed for hybrid operational modes. Besides, operation in autonomous traction accu-battery modes uses direct $0 \times 5$ configuration of traction $3 \times 5 \mathrm{McX}$ matrix converter. Such a configuration can be derived from that main traction converter. Major advantages of simplified connection are beside smaller $4 Q C$ converter size - possible little bit better efficiency of the HEV powertrain. Chosen operational modes of modelling and simulation of traction powertrain configuration are focused on start-up and traction drive of HEV powered by ICE, start-up of ICE powered by AB accu-battery using SG as a starter, and traction drive powered by $A B$ accu-battery and braking of traction motor moving energy into accu-battery $A B$. The results of all simulation experiments are given in the paper.

\section{INTRODUCTION}

The configuration of the recently introduced HEV powertrain uses $A C / A C$ direct power transfer [1]-[3] unlikely to common $A C / D C / A C$ one [4]-[6], Fig. 1. One of the main reason of that is the elimination of input traction rectifier and its voltage drop. Therefore, the efficiency of direct $A C / A C$ power transfer is supposed to be better against to those with VSI and traction rectifier [7]-[8].

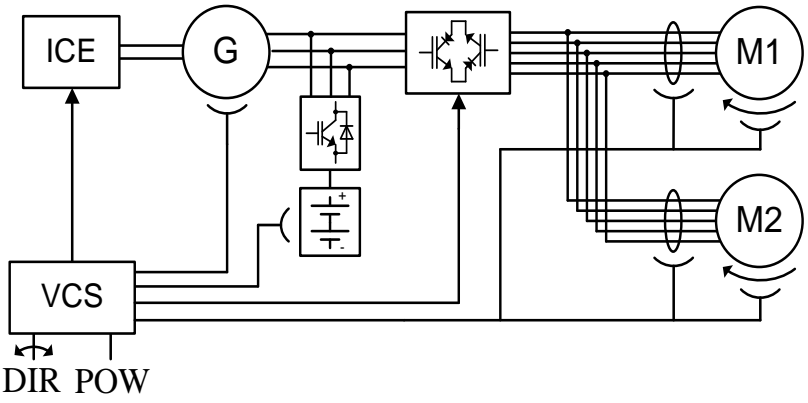

Fig. 1. Schematics of power AC/AC series HEV with one MxC converter and two traction motors with independent control

Anyway, this configuration needs an auxiliary $4 Q C$ converter for battery operational mode. Its sizing should be the same as main AC/AC direct matrix converter. One way how to downsize power and dimensions of the $4 Q C$ converter is to use a group of contactors. It allows providing most of the demanded operational modes of HEV powertrain excepting hybrid modes of ICE engine and traction accu-battery. Advantages of traction motors connection are described in [10]-[12].

\section{A SIMPLIFIED CONNECTION OF HEV ACIAC POWERTRAIN}

The basic scheme of novel simplified configuration of AC/AC HEV powertrain is shown in Fig. 2. The electrical part of powertrain consists of PMSG traction generator, direct AC/AC matrix converter $3 \times 5$ and two traction five-phase induction motor. Traction accubattery is connected by two contactors for traction and recuperation and two others for starting of ICE engine or charging the battery by ICE, respectively.

\subsection{Autonomous operational modes}

Such a configuration can provide following operational modes of HEV powertrain

a - traction drive/brake: ICE-SG-ACAC-5PIM // 5PIM-ACAC-SG-ICE

b - traction drive/brake/charging: AB-ACAC-5PIM // 5PIM-ACAC-AB

c - starting-up/charging: AB-ACAC-SG-ICE // ICE-SG-ACAC-AB.

Those are autonomous operational modes of either ICE engine or traction accu-battery.

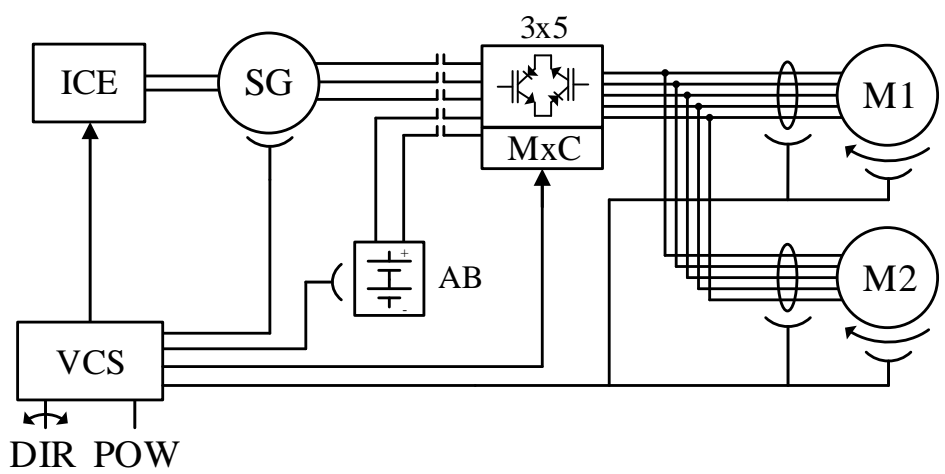

Fig. 2. Novel simplified AC/AC series HEV powertrain with one MXC converter and two traction motors with independent control 


\subsection{Hybrid operational modes}

Hybrid operational mode as the parallel operation of ICE engine and traction accu-battery $A B$ is possible using four-quadrant converter $4 \mathrm{QC}$ only, Fig. 3. However, the sizing of the $4 \mathrm{QC}$ converter is done just for the different power of traction motors and ICE. Practically, it is using during the accelerating regime.

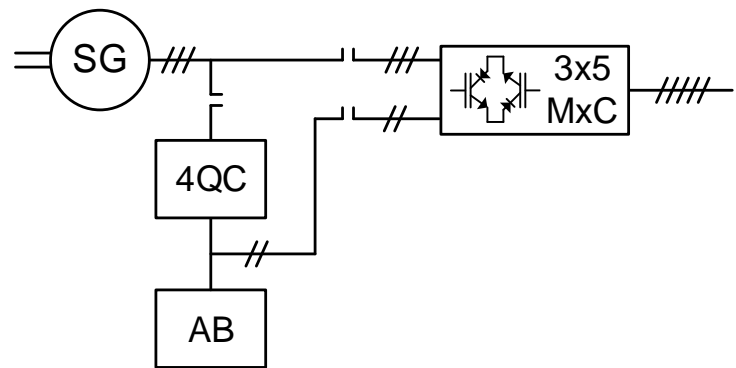

Fig. 3. Hybrid operation possibility: parallel connection of ICE and $A B$ using $4 Q C$ converter

As mentioned, the sizing of paralleling converter $(4 \mathrm{QC})$ is then done just for the different power of traction motors and power delivered by ICE engine.

\section{MODELLING AND SIMULATION IN AUTONOMOUS OPERATIONAL MODES}

Just one traction motor has been taken into account, independent control of two traction motors has not been used at these simulations, so far. Besides, the ICE engine has been modelled by DC motor with separate excitation [2], [9]
Following operational modes have been modelled and simulated:

a) start-up and traction drive of HEV powered by ICE,

b) start-up of ICE powered by $A B$ accu-battery using SG as a starter,

c) traction drive powered by $\mathrm{AB}$ accu-battery and braking (charging) moving energy into accu- battery $A B$.

\section{MODELLING AND SIMULATION IN HYBRID OPERATIONAL MODES}

As mentioned, the configuration model of this operational mode is shown in Fig. 3. Hybrid modes simulation is rather complex, so, such modes could not be modelled and simulated in the paper. Complete powertrain control with both parallel and autonomous modes using the real model of ICE engine is a demanding issue, anyway, it should be done before the development of HEV.

Simulation results are given in Fig. 4a,b and 5a,b.

Parameters of AC/AC powertrain devices are given in table Tab. 1, [2].

Start-up and traction drive of HEV: ICE is starting to idle speed (about $150 \mathrm{rad} / \mathrm{s}$ ). Then, after $3 \mathrm{sec}$., the traction motor is connected via a synchronous generator and $3 \times 5$ matrix converter.

The speed of ICE (and SG, too) is increased to requested value and controlled to this value given by the requested value of traction motor or HEV, respectively. Results of this operational mode are shown in Fig. 4a,b. It deals with detailed waveforms of

Tab. 1. Parameters of $A C / A C$ powertrain devices

\begin{tabular}{|l|l|l|}
\hline \multicolumn{1}{|c|}{ Item } & \multicolumn{1}{|c|}{ Quantity } & \multicolumn{1}{c|}{ Value (dimension) } \\
\hline ICE engine (DC motor, sep. Exc.) & Power & $30 \mathrm{hp} \mathrm{(22} \mathrm{kW)}$ \\
\hline & Armature voltage & $500 \mathrm{~V}$ \\
\hline & Nominal speed & $3000 \mathrm{rpm}$ \\
\hline & Field voltage & $300 \mathrm{Vdc}$ \\
\hline 3 phase PMSG generator: & Power & $11.5 \mathrm{hp}(8.5 \mathrm{~kW})$ \\
\hline & Nominal torque & $27 \mathrm{~N} . \mathrm{m}$ \\
\hline & Nominal speed & $3000 \mathrm{rpm}$ \\
\hline DC bus voltage & Nominal value & $560 \mathrm{Vdc}$ \\
\hline 5 Phase IM induction motor & Power & $7.5 \mathrm{~kW}$ \\
\hline & Nominal torque & $23 \mathrm{N.m}$ \\
\hline & Synchronous speed & $3000 \mathrm{rpm}$ \\
\hline
\end{tabular}
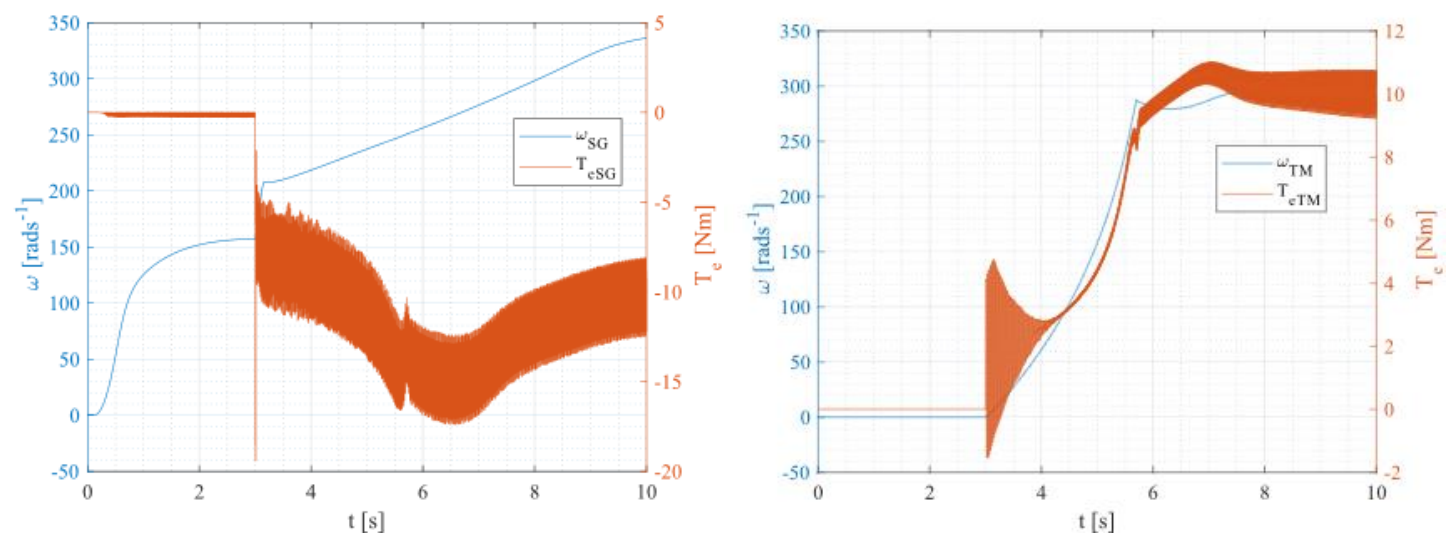

Fig. 4a,b. Details of speed and torque waveforms of SG a) and TM b) during start-up of HEV powered by ICE 
angular speed and torque of traction generator and 5PIM traction motor.

Start-up of ICE engine powered by $A B$ accu-battery using SG as a starter is shown in the Fig. $5 \mathrm{a}$, with detailed waveforms of angular speed and torque of traction generator SG. Note, that this operational mode uses traction $\mathrm{MxC}$ converter in $0 \times 3$ configuration which can be easily derived from $3 \times 5 \mathrm{MxC}$ configuration.

Traction- and recuperation of TM braking energy by/into accubattery $A B$ is enabled by use of traction matrix converter in $0 \times 5$ configuration derived from basic $3 \times 5$ one. Fig. $5, b$ shows the startup of TM to nominal or other requested speed and then, at time of 1 $\mathrm{sec}$, traction operation is changed to regeneration moving energy into the accu-battery. Detailed waveforms of voltage and charging current of traction accu-battery are given.

\section{CONCLUSIONS}

A new simplified configuration of series HEV hybrid vehicles has been introduced in the paper. Simplification consists of the downsizing of auxiliary $4 \mathrm{QC}$ converter needed for hybrid operational modes. The chosen operational autonomous modes of direct AC/AC transfer with [3x5] MxC and five-phase IM traction motors have been presented by means of simulation experiments. They showed good operation at the driving (motoring) and braking actions. Major advantages of using such AC/AC power transfer with [3x5] MxC and five-phase IM traction motors have been mentioned as their higher torque density, smaller voltage drops, smaller torque ripple, greater efficiency, better fault tolerance and better noise characteristics. Hybrid modes simulation is rather complex, and it will be, consequently, investigated in the next publications of the authors.

\section{ACKNOWLEDGEMENT}

The reported study was supported by Slovak Grant Agency VEGA by the grant No. APVV-15-0571. The authors also thank the R\&D operational program Modernization of Research Infrastructure in the Field of Electrotechnics, Electrotechnical Materials and InformationCommunication Technologies, ITMS 26210120021 funded by the European regional development fund (ERDF).

\section{BIBLIOGRAFIA}

1. Dobrucký, B., Kaščák, S., Praženica, M., Pavlásek, P.: Direct AC-AC Propulsion System using Matrix Converter and $5 \varphi$ traction motor for HEV Vehicle. Communications - Scientific Letters of the University of Zilina, 20(1), pp. 3-11, 2018.

2. Dobrucky, B., Kascak, S., Prazenica, M., Drgona, P. Pavlasek, P.: AC/AC powertrain control under different HEV supply network. In: ELEKTRO 2018, 12th International Conference on Electrical Engineering, 21st-23rd May 2018, Mikulov, Czech Republic, pp. TBA, ISBN: TBA - accepted for publication.

3. B. Dobrucky, P. Zaskalicky, P. Pavlasek, "Control of Hybrid-and Electrical Vehicle with Five-Phase IM Motor," AutobusyEfficiency of Transport, 18(6), 1191-1195, 2017.

4. Ehsani M., Gao Y., Emadi A., Modern Electric, Hybrid- and Fuel Cell Vehicles, CRC Press, Boca Raton, USA, 2010.

5. F.A. Wyczalek, Hybrid electric vehicles, Proceedings of the Energy Conversion Engineering Conference and Exhibit (IECEC) 35th Intersociety, vol.1, pp. 349-355, July 24-28, 2000.

6. Hartani K., Bourahla M., Miloud Y., Sekour M., Electronic Differential with Direct Torque Fuzzy Control for Vehicle Propulsion System, Turk J Elec Eng \& Comp Sci, Vol.17, No.1, 2009, () TUBITAK, doi:10.3906/elk-0801-1, no. 6, pp. 21 -38.

7. S. Bernet; S. Ponnaluri; R. Teichmann, "Design and loss comparison of matrix converters, and voltage-source converters for modern AC drives," IEEE Trans. on Industrial Electronics, Vol. 49, No. 2, 2002.

8. Rezaoui M.M., Kouzou A., Mahmoudi M.O., Nezli L., Comparison Performances between Two Matrix Converters [3x3] and [3x5] Supplying a Multi-Phases Induction Machine, Journal of Electrical Engineering, www.jeee.ro.

9. Dobrucký B., Drgoňa P., Hanko B., Electric Servosystem for Turbocharger Vacuum Actuator Replacement, Autobusy, no. 6 (208), 2017, ISSN 1509-5878, pp. CD ROM.

10. Zhang B., Bai H., Pekarek S.D., Eversman W., Krefta R., Holbrook G., Buening D., Comparison of 3-, 5-, and 6-phase machines for automotive charging applications, In Proc. IEEE Int. Electric Machines and Drives Conf. IEMDC, Madison, WI, 2003, CD-ROM paper 10642.

11. Levi E., Jones M., Vukosavic S.N., Toliyat H.A., A novel concept of a multiphase, multi-motor vector controlled drive system supplied from a single voltage source inverter, IEEE Trans. Power Electronics, vol. 19, pp. 320-335, 2004.

12. Jones M., Levi E., Vukosavic S.N., Independent Control of Two Five-Phase Induction Machines Connected in Parallel to a Single Inverter Supply, 1-4244-0136-4/06/\$20.00 '2006 IEEE, pp. 1257-1262.
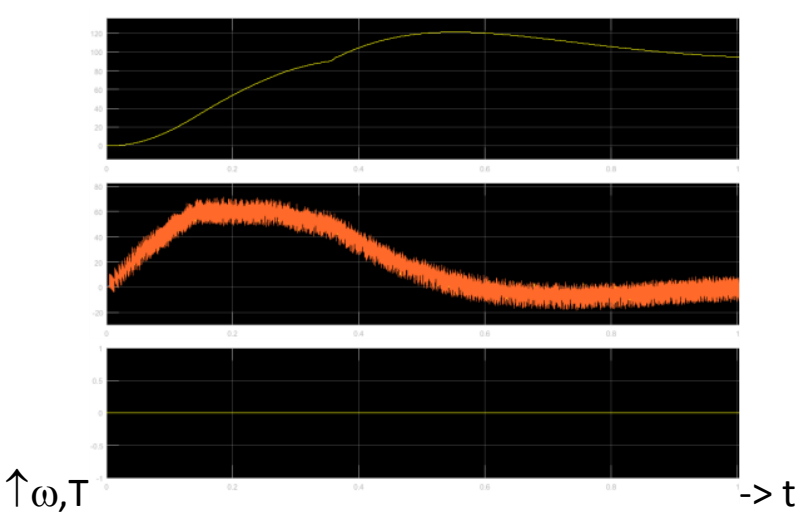

$[\mathrm{s}]$ 个i,u
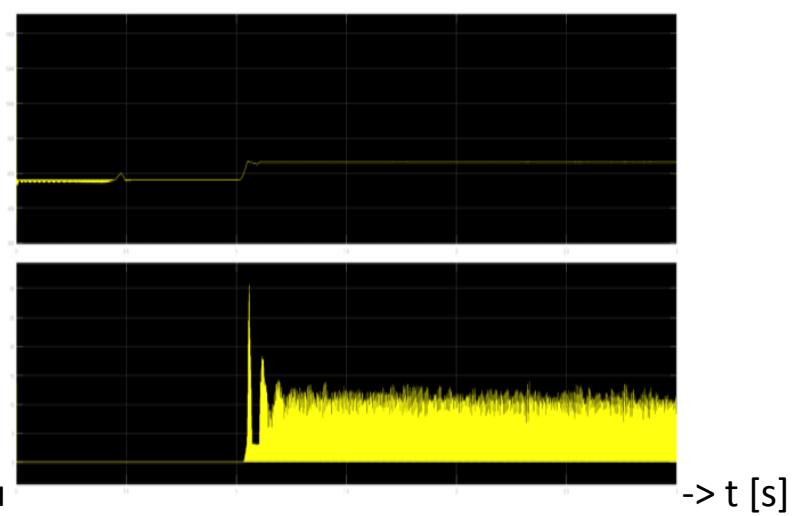

Fig. 5a,b. Start-up of ICE by traction accu-battery using SG as a starter - courses wICE and $T_{\text {ICE }}$ of a) and time waveforms of $u_{A B}$ and $i_{A B}$ during recuperation of TM braking energy $b$ ) 


\section{A Simplified Connection of HEV AC/AC Powertrain}

Artykut dotyczy uproszczonej konfiguracji pojazdów hybrydowych HEV. Uproszczenie polega na zmniejszeniu konwertera $4 Q C$ wymaganego w trybach hybrydowych. Poza tym tryb pracy $w$ trybie autonomicznej trakcji $w$ trybie akumulatorowym wykorzystuje bezpośrednia konfigurację 0x5 trakcyjnego konwertera macierzy $3 x 5$ McX. Taka konfiguracja może być uzyskana z tego głównego konwertera trakcyjnego. Głównymi zaletami uproszczonego połaczenia jest mniejsza wielkość konwertera 4QC - możliwa nieco lepsza wydajność uktadu napędowego HEV. Dostępne sa tryby pracy, modelowanie i uktad napędowy uktadu napędowego skoncentrowany na rozruchu i napędzie trakcyjnym HEV napędzanego przez ICE, rozruch ICE zasilany akumulatorem $A B$ z wykorzystaniem $S G$ jako rozrusznika $i$ napęd trakcyjny zasilany przez $A B$ accu - bateria $i$ hamowanie silnika trakcyjnego, które przenosi energie do akumulatora AB. Wyniki wszystkich eksperymentów symulacyjnych podano $w$ pracy.
Authors:

Prof. Ing. Branislav Dobrucký, Ph.D. - University of Žilina Department of Mechatronics and Electronics. He graduated at the University of Žilina in the field of Electrical Traction and Energetics. E-mail: branislav. dobrucky@fel.uniza.sk.

Assoc. Prof. Peter Drgoňa - University of Žilina - Head of Division of Mechatronics and Autotronics. He graduated at the University of Žilina in the field of Power Electronic System. E-mail: peter.drgona@fel.uniza.sk.

Dr. Slavomír Kaščák - University of Žilina - Department of Mechatronics and Electronics. He graduated at the University of Žilina in the field of Power Electronic System. E-mail: slavomir.kascak@fel.uniza.sk.

Dr. Michal Praženica - University of Žilina - Department of Mechatronics and Electronics. He graduated at the University of Žilina in the field of Power Electronic System. E-mail: prazenica@fel.uniza.sk.

Assoc. Prof. Pavel Pavlásek, Ph.D. - University of Žilina - Department of Mechatronics and Electronics. He graduated at the Slovak Technical University in the field of Electrical Engineering. Email: pavel.pavlasek@fel.uniza.sk.

JEL: L62 DOI: 10.24136/atest.2018.184

Data zgłoszenia: 2018.05.24 Data akceptacji: 2018.06.15 